\title{
Analysis of gravity and aeromagnetic data to determine structural trend and basement depth beneath the Ajdabiya Trough in northeastern Libya
}

\author{
Abdelhakim S. Eshanibli ${ }^{1,3} \cdot$ Abel Uyimwen Osagie $^{2}$ (I) $\cdot$ Nur Azwin Ismail $^{1} \cdot$ Hussin B. Ghanush $^{3}$
}

Received: 15 March 2020 / Accepted: 20 January 2021 / Published online: 27 January 2021

(c) The Author(s) 2021 OPEN

\begin{abstract}
In this study, we analyse both ground gravity and aeromagnetic data in order to delineate structural trends, fault systems and deduce sedimentary thicknesses within the Ajdabiya Trough in Libya's northeast. A high-pass filter and a reducedto-the-pole (RTP) transformation are applied to the gravity and aeromagnetic data respectively. Different filters are used to enhance the structural signatures and fault trends within the study area. The Werner deconvolution and source parameter imaging (SPI) techniques are applied to the RTP magnetic data for source depth estimation. Four well-data within the area are used as constraints in the two-dimensional forward modelling process. The results show that the Ajdabiya Trough is characterised by gravity anomaly highs and magnetic anomaly lows. The analysis of gravity data shows predominant Northeast-Southwest structural trends, whereas the analysis of magnetic data shows predominant NorthSouth magnetic lineaments within the Ajdabiya Trough. The Euler deconvolution depth estimates of faults depths range between 1500 and $9500 \mathrm{~m}$. The SPI estimates of the magnetic basement range between 2500 and 11,500 m beneath the study area (deepest beneath the Ajdabiya Trough). Constrained by the well-data, six major layers characterize the four profiles that are taken within the area. One of the profiles shows a high-density intrusion (about $4 \mathrm{~km}$ from the surface) within the sedimentary sequence. The intrusion may be the result of the rifting Sirt Basin which caused a weakening of the crust to allow for mantle intrusion.
\end{abstract}

Keywords Ajdabiya Trough · Gravity and aeromagnetic · Structural trend · Basement

Mathematics Subject Classification $86 \mathrm{~A} 11$

JELClassification Q39

\section{Introduction}

The Sirt Basin has been described as a triple-junction rift along the northern margin of the African crust in northcentral Libya [1]. The structural features of the basin are largely due to tectonic interactions between the African and the Eurasian plates. The Ajdabiya Trough located northeast of the Sirt Basin is the youngest sedimentary basin in Libya. The trough is believed to be the main depocenter of the Oligocene and Miocene sediments [2] and expected to be one of the most promising areas for hydrocarbon exploration. According to [3], about $8500 \mathrm{~km}^{2}$ due South of the Ajdabiya Trough is underexplored. This region is among the six underexplored basin centres with petroleum potential in Libya [3-5]. The structure and stratigraphy of central Ajdabiya Trough is poorly known because

$\triangle$ Abel Uyimwen Osagie, abel.osagie@uniabuja.edu.ng| 'School of Physics, Universiti Sains Malaysia, 11800 Pulau, Penang, Malaysia. ${ }^{2}$ Department of Physics, University of Abuja, P.M.B 117, Abuja, Nigeria. ${ }^{3}$ Libyan Petroleum Institute (LPI), Tripoli 6431 , Libya. 
exploration activities around the trough focus mostly on the shallow basin flanks and adjacent platforms [6]. The complex geological setting, particularly to the North of the Ajdabiya Trough further complicates the present understanding of the structural trend. More so, there is little information about the deep structures which can play an important role in the geometry of potential hydrocarbon accumulation.

The study region spans latitudes $29.25^{\circ} \mathrm{N}-30.75^{\circ} \mathrm{N}$ and longitudes $19.55^{\circ} \mathrm{E}-20.75^{\circ} \mathrm{E}$ within which is the Ajdabiya Trough (Fig. 1). Integrating geological and geophysical data to determine nine facies of reservoir units southeast of the Ajdabiya Trough, Abdelnabi et al. [7] observed that faults mostly control the distribution and thickness of one of the reservoir units. A 3D (three-dimensional) seismic survey [8] showed a channel-like feature (of submarine origin) within the southern part of the trough (called the Intisar E field). Some pinnacle reefs in the Intisar complex contained hydrocarbon reservoirs while adjacent reefs are barren due to a cut in the channel that supplied carbonate debris in the late stages of the reefs' growth [8]. Submarine scouring caused turbidity currents through the channel that resulted in carbonate sedimentation in the hydrocarbon reservoirs [8].

That the accumulation of hydrocarbon can be controlled structurally (e.g. Abdelnabi et al. [7]) is an important justification to examine the structural trends by analysing

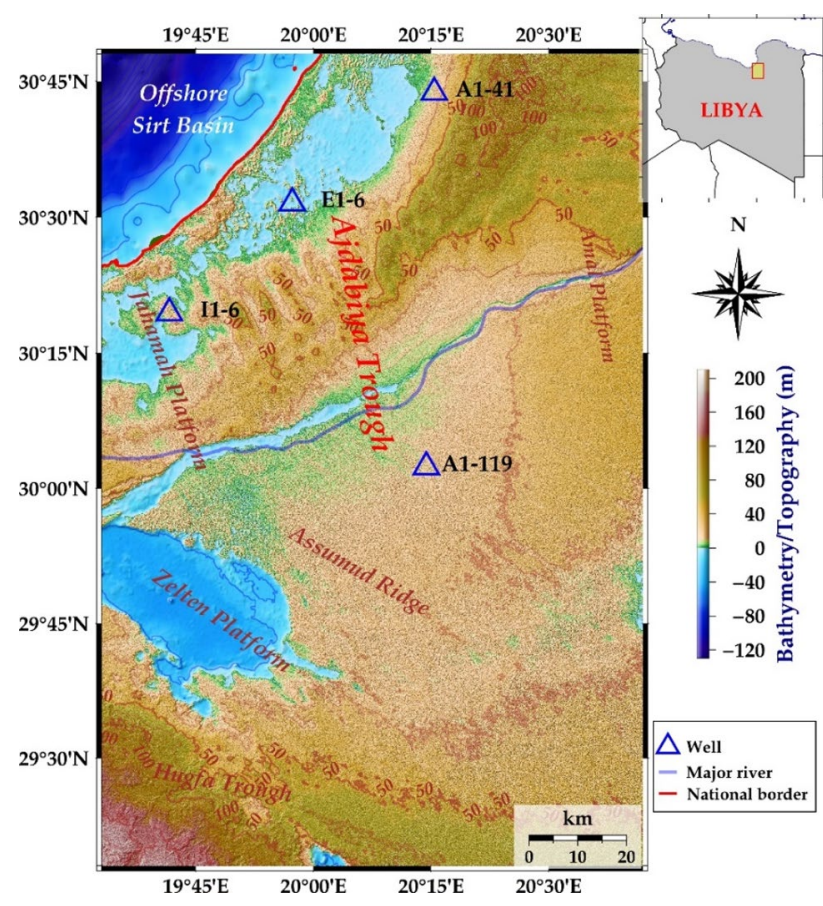

Fig. 1 Topography and bathymetry map of the study area showing the various troughs, platforms and the location of four oil wells (blue triangles) the available geophysical datasets. Hence, this study attempts to (1) obtain the structural trend and fault systems within the Ajdabiya Trough; (2) determine the depth to the magnetic basement beneath the trough. The depth of magnetic basement can help to calculate the shape of the sedimentary basin. Qualitatively, different filters will be applied to both the ground gravity and the aeromagnetic data over the study area to discern the structural trends, magnetic lineaments and to identify the fault systems. Also, quantitative analysis will be carried out to obtain a 2D (two-dimensional) model that best approximates the anomalies observed from the geophysical datasets.

Previously, numerous investigations, e.g. [1, 9-19] have provided information about the Sirt Basin but few published reports (based on the analysis of potential field data) focus on the Ajdabiya Trough. Recently in 2010, a qualitative subsurface investigation by Saheel et al. [20] concluded that different basement structure exists in opposite flanks of the trough. The study was however limited to the use of a few filters (only a high-pass filter at $150 \mathrm{~km}$ cut-off wavelength was applied to the gravity data while the total horizontal gradient was applied to both the gravity and aeromagnetic data). Later in 2011, using aeromagnetic data over the Sirt Basin, Saheel et al. [21] deduced different fault trends in the NE-SW, N-S and NW-SE directions within the trough and attributed the faults to different tectonic events within the basin. Using decompaction and back-stripping to quantify the tectonic subsidence of the trough, Ghanush et al. [6] reported that the subsidence brought a modification of a basin-style within the Cenozoic period in the form of convex-upward for a short and quick subsidence stage. Ghanush et al. [6] attributed the cause to the installation of Late to Early Eocene arrangements between 55 and $50 \mathrm{Ma}$. The basement subsidence curves for the Ajdabiya Trough [6] have a good correlation with the results of earlier studies e.g. [22-25]. More recently, [26] investigated the structure and stratigraphy of the Ajdabiya Trough using potential field and $2 \mathrm{D}$ seismic reflection data to identify predominant NW-SE fault trends (which penetrated the Cretaceous sediments) as well as NE-SW and E-W fault trends (that penetrated the Miocene and older strata). The faults [26] are several hundred meters apart with large throws on the Cretaceous and underlying horizons.

\section{Geological setting and basement structure of the study area}

The Pan-African and Paleozoic structures (which make up the basement beneath Libya) trend in different directions and have a gentle to moderate dip to the southeast of Libya [10-27]. Although intrusive rocks have been 
reported to form the widest segment of the crystalline basement series, e.g. $[9,27]$, the basement rocks of the Sirt Basin are considerably undifferentiated stratigraphy due to inadequate data. A simplified geological map of the Sirt Basin (Fig. 2) shows the different rock units within the region. From petrography related drilling and geochemical studies, pre-pan-African metamorphic rocks such as schists have been suggested to characterize the basement [28] due south of the study area. To the North of the Ajdabiya Trough, the basement contains mica-schists, graphite-mica-schist rocks $[9,29,30]$. These rocks were ranked lithostratigraphically to the Late Proterozoic and Cambrian [29]. The Ajdabiya Trough extends from the Kalanshiyu High in the South through the northern margin of onshore Sirt Basin to the Mediterranean Sea "offshore Sirt Gulf" [31, 32]. Block faulting has been reported [10-27] along the NNW-SSE to NW-SE zone of weakness that cross-cut Paleozoic structures at a high angle but possibly parallel to some of the basement shear zones.

Discussing the four main phases (Late Jurassic to the Early Cretaceous, Late Cretaceous, Paleocene and Middle Eocene) of uplifting and subsidence within the Sirt Basin, Kassab et al. [33] reported active subsidence along the NW trending structure within the Ajdabiya Trough which started in the Middle Eocene and continues till date. According to [26], variations in the sea level and/or sedimentation during Late Mesozoic and Cenozoic periods correlate with the seismic stratigraphy of the trough. Progradation of the Paleocene, Early and Middle Eocene sequences along the trough margin suggests rapid sedimentation with a slow increase in accommodation [26]. The 2D model [34] shows a major N-S trending strike-slip fault set, igneous intrusions and other structural elements beneath the Ajdabiya Trough. However, only a single profile was taken and with only one well data. More so, the model [34] did not explicitly discern the depth to basement around the trough which is part of the objective of this study.

\section{Methodology}

\subsection{Data}

Ground gravity survey data are obtained from the Libyan Petroleum Institute (LPI). The LPI collaborates with the

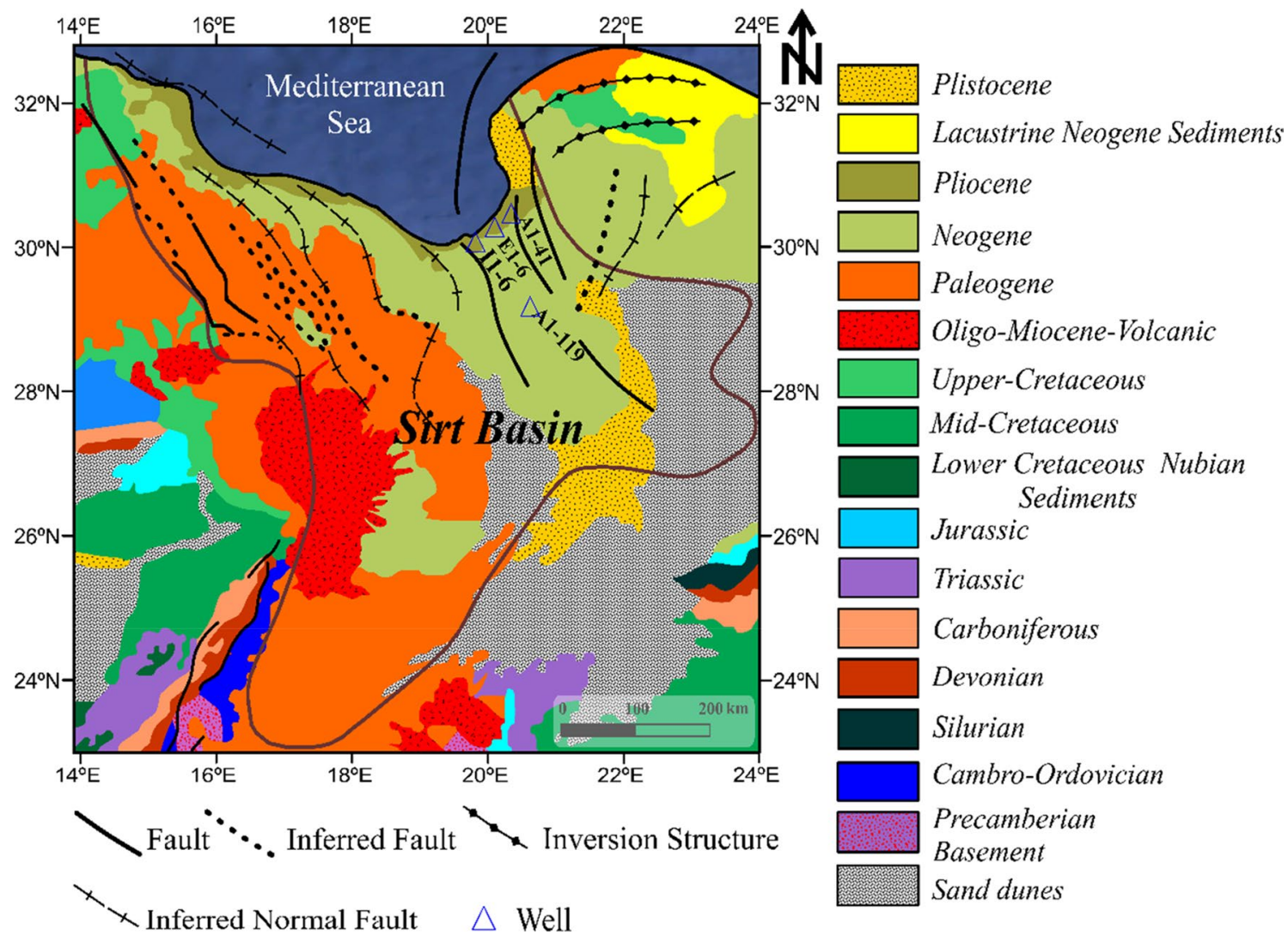

Fig. 2 A simplified geological map of the Sirt Basin showing the distribution of rock units and major structural elements (modified after [2]). The brown line shows the boundary of the Sirt Basin 
Table 1 Formation tops of well data used in this study (Libyan National Oil Corporation)

\begin{tabular}{|c|c|c|c|c|}
\hline \multirow[t]{2}{*}{ Lithology } & Well I1-6 & Well A1-41 & Well A1-119 & Well E1-6 \\
\hline & \multicolumn{4}{|c|}{ Formation tops (m) } \\
\hline Pliocene & 100 & - & - & 100 \\
\hline Miocene & 750 & 75 & - & 680 \\
\hline Oligocene & 1800 & 1200 & 92 & - \\
\hline Eocene & 2670 & 2840 & 1500 & - \\
\hline Palaeocene & 3680 & 3920 & 2985 & - \\
\hline Mesozoic & 4280 & - & 4000 & - \\
\hline Total Depth & 4604 & 4179 & 4146 & 1200 \\
\hline
\end{tabular}

Table 2 Rock densities used in 2D modelling $[35,36]$

\begin{tabular}{llll}
\hline Unit & Density $(\mathrm{g} / \mathrm{cc})$ & Unit & Density $(\mathrm{g} / \mathrm{cc})$ \\
\hline Pliocene & 2.30 & Mesozoic & 2.50 \\
Miocene & 2.38 & Paleozoic & 2.54 \\
Oligocene & 2.40 & Basement & 2.67 \\
Eocene & 2.45 & Intrusion & 2.79 \\
Palaeocene & 2.48 & - & - \\
\hline
\end{tabular}

Libyan Gravity Project (LGP) and the Libyan National Oil Corporation (NOC). The NOC obtains data from numerous oil and gas companies that operate in Libya. The gravity data consist of 74,520 data points taken at $1.0 \mathrm{~km}$ station separation across the study area. A reduction density of $2.67 \mathrm{~g} / \mathrm{cm}^{3}$ based on the Geodetic Reference System 1980 (GRS 80) datum reference had been used to obtain the Free-air and Bouguer corrections. Latitude and terrain corrections had also been applied prior to obtaining the gravity data. The aeromagnetic data are obtained from the African Magnetic Mapping Project (AMMP). The AMMP is part of a worldwide collaboration between Peterson, Grant and Watson Limited (PGW, Canada), Getech (UK) and the International Institute for Geo-Information Science and Earth Observation (ITC, in the Netherlands). Flight lines and data points along each line are both $1.0 \mathrm{~km}$ apart. About 22,270 magnetic data points are obtained from 113 flight lines in the $\mathrm{E}-\mathrm{W}$ direction. Well-data from four boreholes within the study area (Fig. 1) are used to constrain the 2D models. The NOC also provided the formation tops of the four wellsA1-119, A1-41, E1-6 and 11-6 (Table 1). The rock densities used in this study are estimated from both borehole data and rock densities (Table 2) that have been measured $[35,36]$. A total of nine continuous density well logs and 781 core samples from 31 wells have been used to determine the rock densities for the whole of Libya $[35,36]$.

\section{Data analysis}

All applicable corrections had been applied to the gravity data from the LPI, such as Drift, Latitude, Free-Air, Bouguer and terrain corrections. The AMMP took aeromagnetic data points at $1.0 \mathrm{~km}$ grid and a constant $1.0 \mathrm{~km}$ terrain clearance with the appropriate corrections (e.g. diurnal, geomagnetic corrections). The raw data show Bouguer anomaly lows and highs as well as magnetic anomaly lows and highs with respect to their background values within the study area. The Oasis Montaj software provided by the LPI is used to analyse both the gravity and magnetic data. The "minimum curvature" gridding is applied to the data points. A high-pass filter is applied to the gravity data to obtain the residual gravity anomaly. In the process, cut-off wavelengths are gradually increased in multiples of $5 \mathrm{~km}$. The $50-\mathrm{km}$ cut-off wavelength produced the smoothest regional trend. To minimize polarity effects, a reduction-to-thepole (RTP) filter is applied to the magnetic data. The RTP filter restores the spatial shift in the peak of anomalies caused by the vector nature of the magnetic field and centre them to be on top of the causative anomalies. The RTP process assumes uniformity in the direction of magnetisation throughout the causative body and a uniform geomagnetic field throughout the study region which may not be accurate for large areas [44]. The ambient magnetic field taken at coordinates $20.00^{\circ} \mathrm{N}$ and $30.25^{\circ} \mathrm{E}$ within the study area is calculated from the IGRF formula (2008) to have an inclination of $42.6^{\circ} \mathrm{N}$ and a declination of $1.46^{\circ} \mathrm{E}$.

The flow chart (Fig. 3) illustrates the entire process in this study. Enhancement techniques such as the total horizontal gradient (THG), e.g. [37, 38], tilt angle derivative (TAD) [39] and the Centre for Exploration Targeting (CET) grid analysis [40] are applied to both the residual gravity and RTP grids. The THG method has low sensitivity to noise in datasets because only the two first-order horizontal derivatives of the field are required [41]. The TAD method normalises the ratio of vertical and the total horizontal derivatives of the grid. The CET grid analysis identifies the density discontinuity using a combination of texture analysis and bilateral symmetric feature detection. The CET operation calculates the standard deviation of the data values at each location in the grid. Compared with the background signal, a highly variable computational value suggests the presence of significant features.

Furthermore, the 3D Euler deconvolution (ED) method (applied to both the gravity and magnetic anomaly grids) is used to estimate fault depths. The ED uses the first vertical derivatives in three dimensions $(x, y$, and 


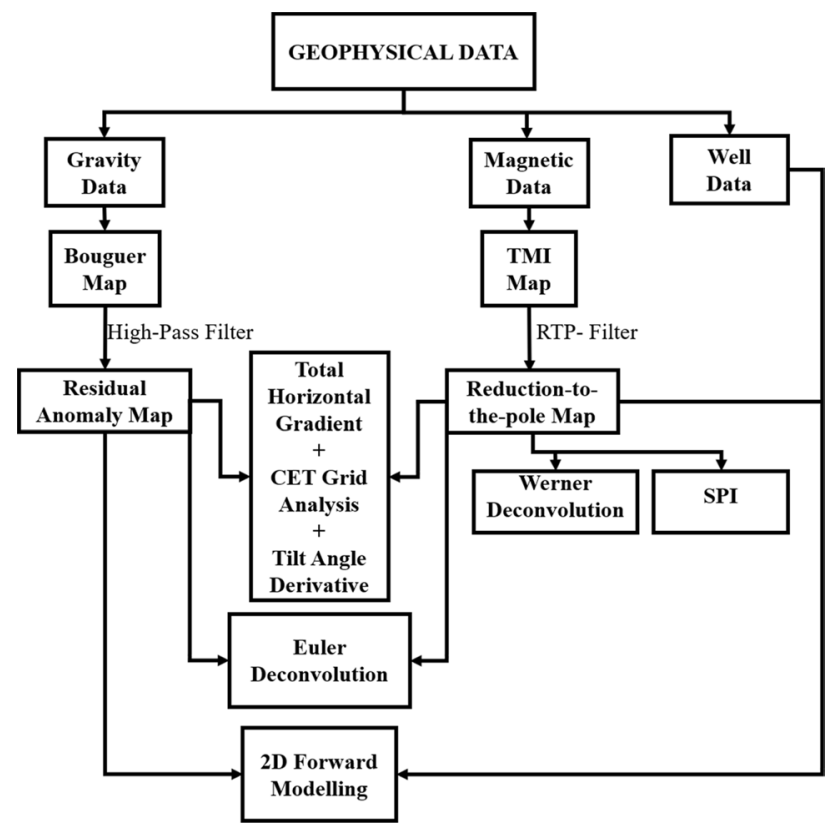

Fig. 3 A flow chart of the methodology used in this work

$z$ ) to determine location and depths to anomalous targets. The ED technique estimates the source location of the causative anomalies by assuming the type of body which is defined by a specified Structural Index (SI) prior to computation. A window size of 8 by 8 cell units and a maximum depth tolerance of $18 \%$ is used for both grids. Following the recommendation of [42], the $\mathrm{SI}$ is set to 0 for gravity and 1 for the magnetic grids. The Werner deconvolution (WD) [43] and the Source Parameter Imaging (SPI) techniques [44] are applied to the RTP magnetic anomaly grid to estimate the depth to the magnetic basement. The WD is a 2D-based profile method which assumes that the magnetic source is also 2D. With this assumption, the horizontal derivative of the magnetic anomaly can be calculated for the observed profile. The SPI technique (sometimes referred to as the local wave number method) is based on the relationship between the source depth and the local wave number (K) of the analytic signal of the observed field [44]. The SPI method is independent of remanent magnetization or other magnetic parameters like inclination, declination, dip and strike. However, the SPI method requires the first- and second-order derivatives of the magnetic field (to obtain the first- and second-order wave numbers), which can amplify noise in the data and be affected by interference. After the application of the above stated techniques, the resulting grids are exported from the Oasis Montaj software and the Generic Mapping Tools (GMT) version 6.1 software [45] is used to visualize all but the ED grid which was difficult to extract from the Oasis
Montaj software as a comma-separated-value (csv) file. Instead, the Surfer v16 software is used to visualize the exportable ED grid file format.

For modelling purposes, four long profile lines are taken across sections of the study area. The profile lines are labelled from letter $\mathbf{A}$ through $\mathbf{D}$ (Fig. 4). Three of the profile lines (A, B and $\mathbf{C}$ ) are taken across the Ajdabiya Trough in the $\mathrm{E}-\mathrm{W}$ direction while profile $\mathbf{D}$ is taken in the SE-NW direction. The 2D forward modelling $[46,47]$ is applied to both the residual gravity anomaly and the RTP grids. Magnetic anomalies (Table 3 ) are obtained based on the formulation by [48]. The profile ends are extended to avoid edge effects. The geological models across the study area are created by the GM-SYS profile modelling extension of Oasis Montaj. The GM-SYS allows for the creation of a model and to perform validation test on the potential field responses to the observed measurements.

\section{Results}

\subsection{Bouguer and total magnetic intensity anomaly maps}

Bouguer gravity anomaly highs (GAH) trend mainly NW-SE (Fig. 4a) while magnetic anomaly lows (MAL) trend predominantly NE-SW and N-S in the central part of the study area (Fig. 4b). The Ajdabiya Trough is characterized by GAH and MAL (Fig. 4a, b) respectively. To the East of the Ajdabiya Trough, part of the Amal Platform shows both GAH and gravity anomaly lows (GAL), as well as MAL which gradually increase southwards. The Assumud Ridge which is due South of the Ajdabiya Trough also shows GAH and MAL. The Jahamah Platform and the Hugfa Trough to the west and southwest respectively of the Ajdabiya Trough show GAL and magnetic anomaly highs (MAH) with respect to the background values. GAH and MAL characterise the Zelten Platform, southwest of the Ajdabiya Trough. The highest and lowest gravity anomaly values are around the Ajdabiya and the Hugfa Troughs respectively. On the other hand, the highest and lowest magnetic intensity anomaly values are southeast of the Ajdabiya Trough.

\subsection{Residual gravity and reduction to the magnetic pole anomaly maps}

The residual Bouguer anomaly map (Fig. $5 \mathrm{a}$ ) shows similar GAH as Fig. 4a, trending NW-SE around the Ajdabiya Trough, but GAL is observed in the eastern section of the trough. Southwest of the trough, the Assumud Ridge and Zelten Platform are also characterized by GAH. Meanwhile, GAL and GAH characterise the Jahamah Platform. 

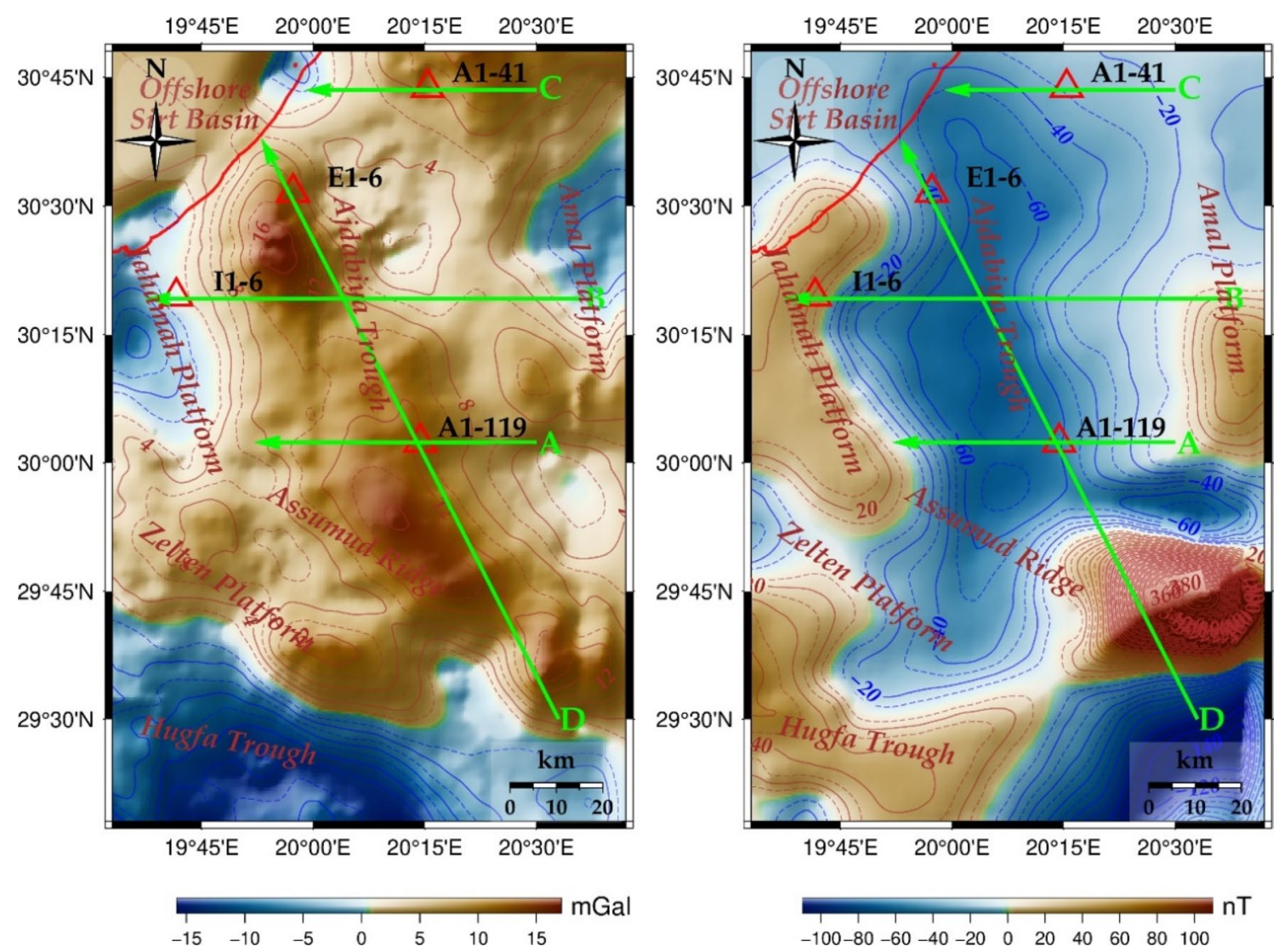

$-100-80-60-40-20 \quad 0 \quad 20 \quad 40 \quad 60 \quad 80 \quad 100$

Fig. 4 a Bouguer anomaly map, b total magnetic intensity anomaly map. In both maps, brown and blue colours represent anomaly highs and lows respectively. (Green lines A-D are profile lines for 2D modelling purposes)

Table 3 Magnetic susceptibility values used in the study [38]

\begin{tabular}{llll}
\hline Unit & Susceptibility (cgs) & Unit & Susceptibility (cgs) \\
\hline Pliocene & 0.0000025 & Mesozoic & 0.0000543 \\
Miocene & 0.0000047 & Paleozoic & 0.0000628 \\
Oligocene & 0.00000513 & Basement & 0.00438 \\
Eocene & 0.0000212 & Intrusion & 0.003 \\
Paleocene & 0.0000218 & - & - \\
\hline
\end{tabular}

The GAL appears to widen within the Amal Platform. The GAH with NW-SE orientations around Ajdabiya Trough (Fig. 5a) may be referred to the Early Cretaceous. The RTP map (Fig. 5b) shows a broader MAH within the Ajdabiya Trough and bounded by MAH around the Amal and Jahamah Platforms. This steep gradient of magnetic anomaly refers to a strong NNW-SSE structural trend truncated by a N-S trend between the Ajdabiya Trough and the Amal Platform. The Hugfa Trough is characterized by both MAL and MAH. The Ajdabiya Trough shows MAL.

\subsection{Edge detection and fault depths}

The steepest portion of the magnetic anomaly is usually the effect of abrupt lateral change in rock properties at dipping contacts. The THG (of residual Bouguer anomaly grid) map accentuates the NW-SE structural trends within the Ajdabiya Trough (Fig. 6a). The THG (of the RTP grid) map (Fig. 6b) did not discern the magnetic lineament clearly around the Ajdabiya Trough but shows discernable magnetic signatures southwest of the trough. The TAD value is about zero near the source edges. A positive TAD value indicates a positive contrast of the causative source while a negative value is outside the source limits. The TAD (of residual Bouguer anomaly grid) map shows dominant trends (with positive contrast) in the NE-SW and NNE-SSW directions (Fig. 7a). On the other hand, the TAD (of the RTP grid) map shows a dominant $\mathrm{N}-\mathrm{S}$ trend (with positive contrast) within the Ajdabiya Trough (Fig. 7b). The CET grid analyses of the residual Bouguer anomaly grid (Fig. 8a) and the RTP grid (Fig. 8b) show predominant NW-SE and N-S trending faults respectively around the Ajdabiya Trough. The reason for this trend is unclear. The NW-SE trending faults 

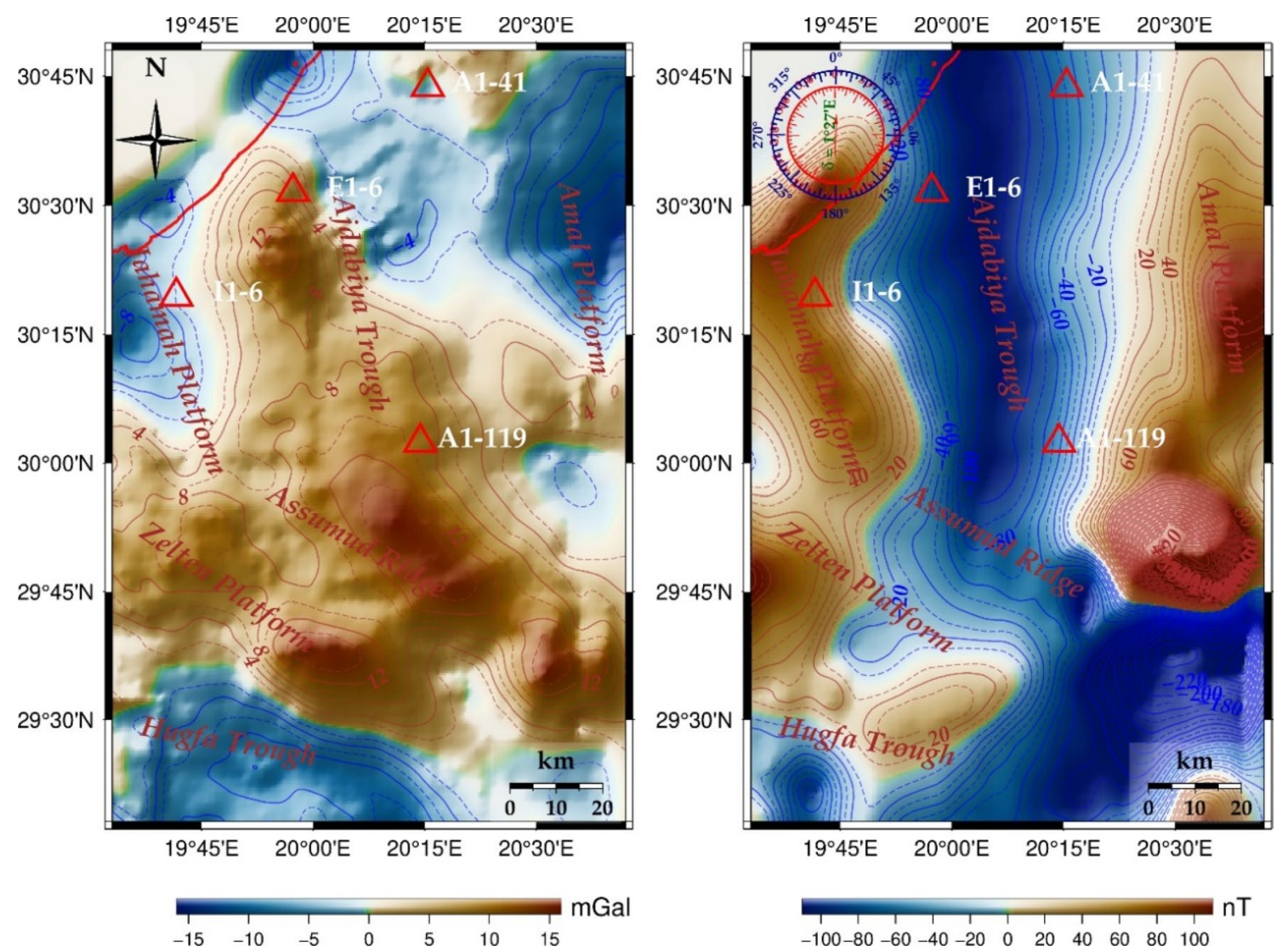

Fig. 5 a Residual Bouguer anomaly map at $50 \mathrm{~km}$ cut-off wavelength, b RTP magnetic anomaly map

may have contributed to the development of the basement beneath the Zelten Platform and Hugfa Trough.

The Euler solutions (Fig. 9) corroborate the trends from the application of CET grid. The Euler solution map for gravity anomaly (Fig. 9a) shows NW-SE trending faults with depths ranging between 1800 and $7500 \mathrm{~m}$ while the magnetic counterpart (Fig. 9b) shows a wider range of fault depths (between 1200 and $9500 \mathrm{~m}$ ). At these depths, the faults are expected to permeate the Cenozoic and Mesozoic sedimentary sections. This indicates a thick sedimentary sequence beneath the region. Areas within the Ajdabiya Trough show a depth range between 3500 and $9500 \mathrm{~m}$ with NNW-SSE trends.

\subsection{Source depth estimation}

The SPI map (Fig. 10) shows that magnetic source is deepest (more than 10,500 m) beneath the Ajdabiya Trough. The application of Werner deconvolution (WD) indicates the existence of an intrusive body beneath one of the profile lines (profile line $\mathbf{D}$ ). The WD result shows both GAH and MAH southwest of the Ajdabiya Trough (black oval, Fig. 11). The causative body is estimated to be around $4000 \mathrm{~m}$ below the surface. The existence of this body (assumed to be a dyke) is the result of volcanic activities that occurred during the Cenozoic.

\subsection{D forward modelling}

Figure $12 \mathrm{a}-\mathrm{d}$ shows the results of $2 \mathrm{D}$ forward modelling of the four profile lines (A to $\mathbf{D}$ ) respectively. The magnetic susceptibility values used are based on the formulation by Clark and Emerson [48]. In Fig. 12a, Well A1-119 (4146 m deep) stopped in the Paleocene strata. Crustal extension at different times is believed to cause faulting represented by the three normal faults (F1, F2 and F3). The inferred blind faults appear to penetrate the sedimentary sequence with $F 1$ and $F 3$ truncating in the basement while $F 2$ ends in the Paleozoic strata. The faults have been identified by the Euler deconvolution solution map (Fig. 9a). The basement appears shallower on the western flank when compared with the eastern side of the Ajdabiya Trough.

Moving northwards from profile $\mathbf{A}$ the 2D model constructed along profile line $\mathbf{B}$ (Fig. 12b) also shows three normal faults ( $F 4, F 5$ and $F 6$ ) which may be a continuation of faults $F 1, F 2$ and $F 3$ respectively. However, only faults $F 5$ and $F 6$ appear to reach the basement. On the left of the figure is Well 11-6 (4604 m deep) which ends 

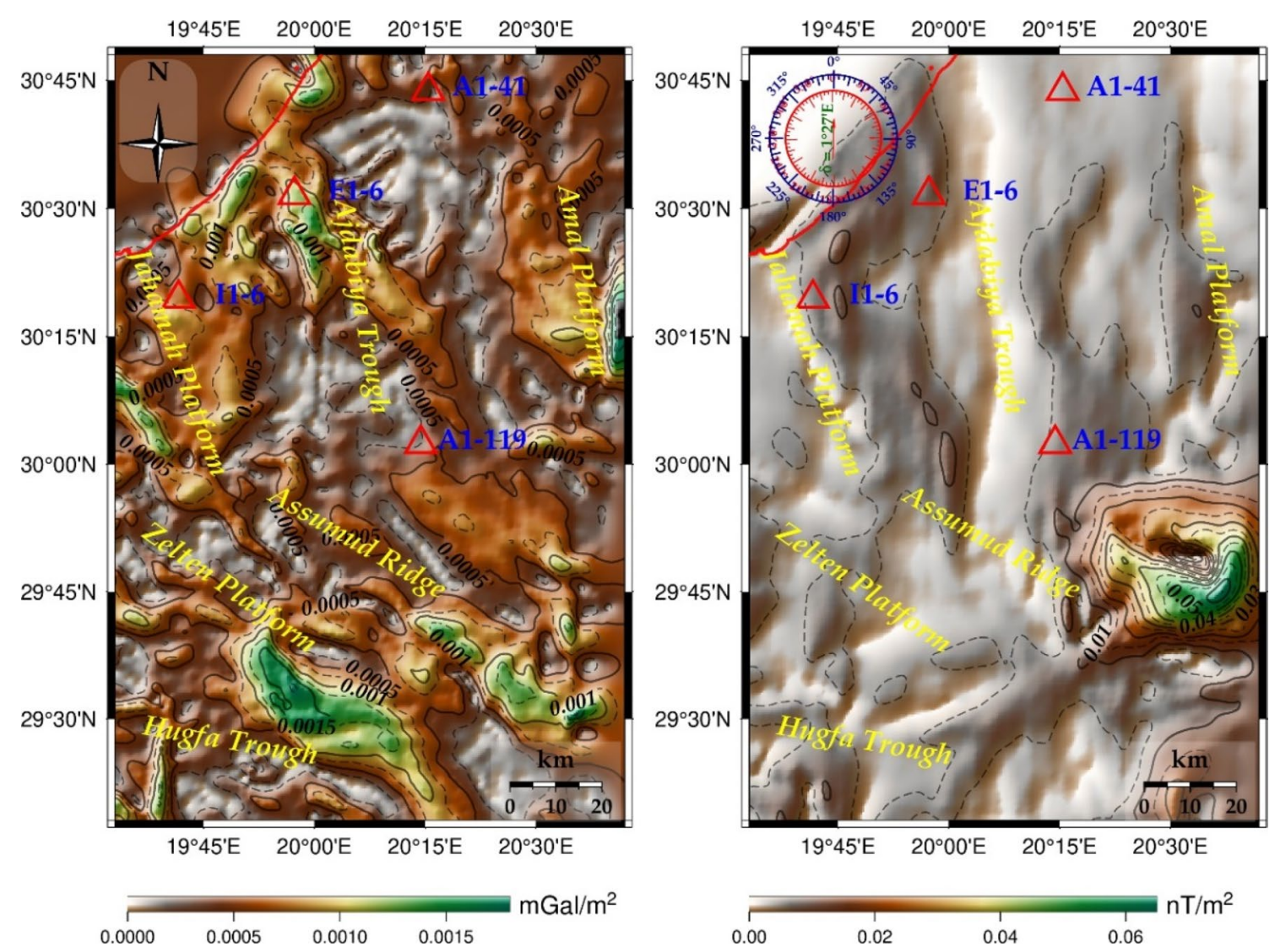

Fig. 6 Total horizontal gradient (THG) map of a residual Bouguer anomaly, b RTP magnetic anomaly

in the Paleocene strata. The basement along this profile appears relatively horizontal.

Further north from profile line $\mathbf{B}$, the 2D model constructed along profile line $\mathbf{C}$ (Fig. 12C) traverses the less steep northeastern magnetic anomaly gradient of the Ajdabiya Trough seen in the TMI map. Well A1-41 (4179 $\mathrm{m}$ deep) starts from the Miocene strata. This is due to irregular sedimentation during the Miocene. The area was later eroded. Sedimentation during the Pliocene continued around Wells I1- 6 and E1- 6 but not around the region surrounding Well A1-41. Two normal faults (F7 and F8) are inferred and the basement appears deeper on the East when compared with the West of the profile.

The 2D model (Fig. 12d) constructed along profile line D shows two faults F9 and F10 that reflect the movements within the crust. Rifting of the Sirt Basin caused extensional forces that weakened the crust to cause mantle intrusion observed as both $\mathrm{GAH}$ and $\mathrm{MAH}$ in their respective maps. However, the high-density intrusion includes some modelling uncertainties and may be further modified. The intrusion which may be basaltic is the result of local uplifting during the Cenozoic [2].

\section{Discussion}

The gravity and magnetic maps indicate that the Ajdabiya Trough is characterized by elongated GAH that trend NW-SE and MAL that trend N-S, showing a strong correlation with the structural highs (associated with platforms) and the structural lows (associated with sedimentary filled troughs) known from drilling. The Ajdabiya Trough is flanked by gravity and magnetic gradients. The RTP magnetic map shows MAH to the East and West of the trough. The MAL observed within the trough is due mainly to the presence of low susceptibility rocks. 

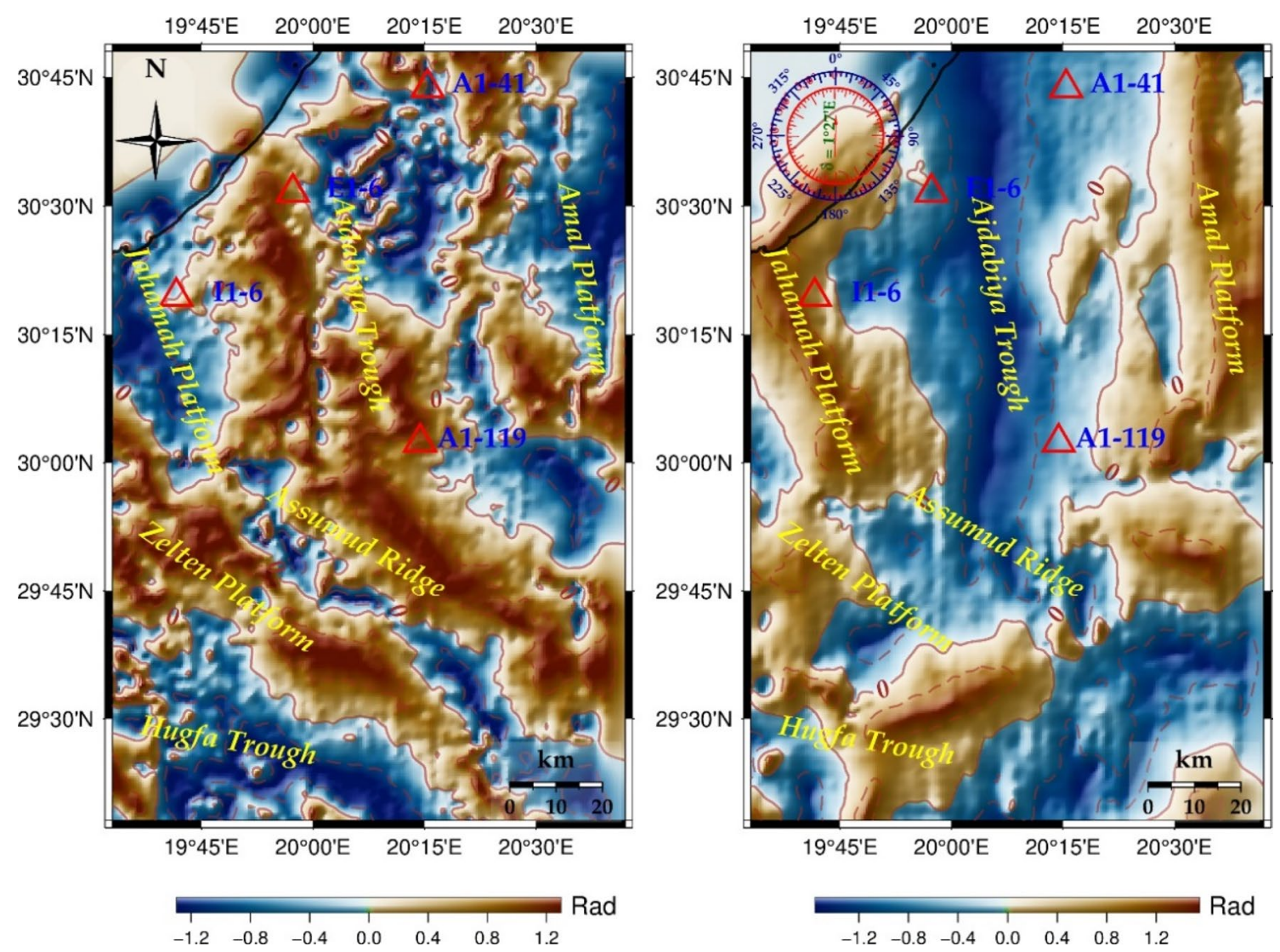

Fig. 7 Tilt angle derivative (TAD) map of a residual Bouguer anomaly, b RTP magnetic anomaly

It is important to emphasize that the terrain clearance of the magnetic data used in this study is $1 \mathrm{~km}$. At this constant terrain clearance, closely spaced magnetic units within rocks may exhibit anomalies as single features or a continuous pattern. The horizontal dimension of an anomaly over magnetic sources increases in direct proportion to the terrain clearance. However, the interesting anomaly falls within a factor of five times the source-sensor separation and due to a large terrain clearance, the resolution of geological detail may be compromised by the horizontal component of the anomaly over all other compact magnetic sources [49]. The magnetic signatures are extended more in an E-W direction due to magnetic sources in low latitudes [49]. Fortunately, the E-W flight lines (which is nearly normal to the principal geological strike) are best suited for the region of this study.

The various enhancement techniques (THG, TAD and CET grid analysis) accentuated the structural and magnetic lineaments. This study obtains structural trends similar to those obtained previously [34] and identified more fault systems. The gravity data analysis shows predominant NW-SE trending structures and inferred faults, whereas the analysis of magnetic data delineated structures and fault systems that are $\mathrm{N}-\mathrm{S}$ predominantly. That lithological boundaries often follow boundaries in magnetic properties allow the trend in magnetic anomaly observed in this study to be associated with structural trends. The study area is characterized by fault systems along with subordinate faults of variable trends and strikes. These trends represent the faults that occurred after the Pan-African Orogeny. It is unclear whether the faults are connected with the $\mathrm{N}-\mathrm{S}$ extensions along the edge of the Neo-Tethys [30, 50-52]. The NW-SE trending faults may have been reactivated during the Late Permian-Triassic and developed along a marginal zone of extended crust, partitioned by major Pan African NW-SE trending crustal fracture zones, e.g. [10]. This trend could also be related to a reactivated Hercynian or older basement structure [53]. 

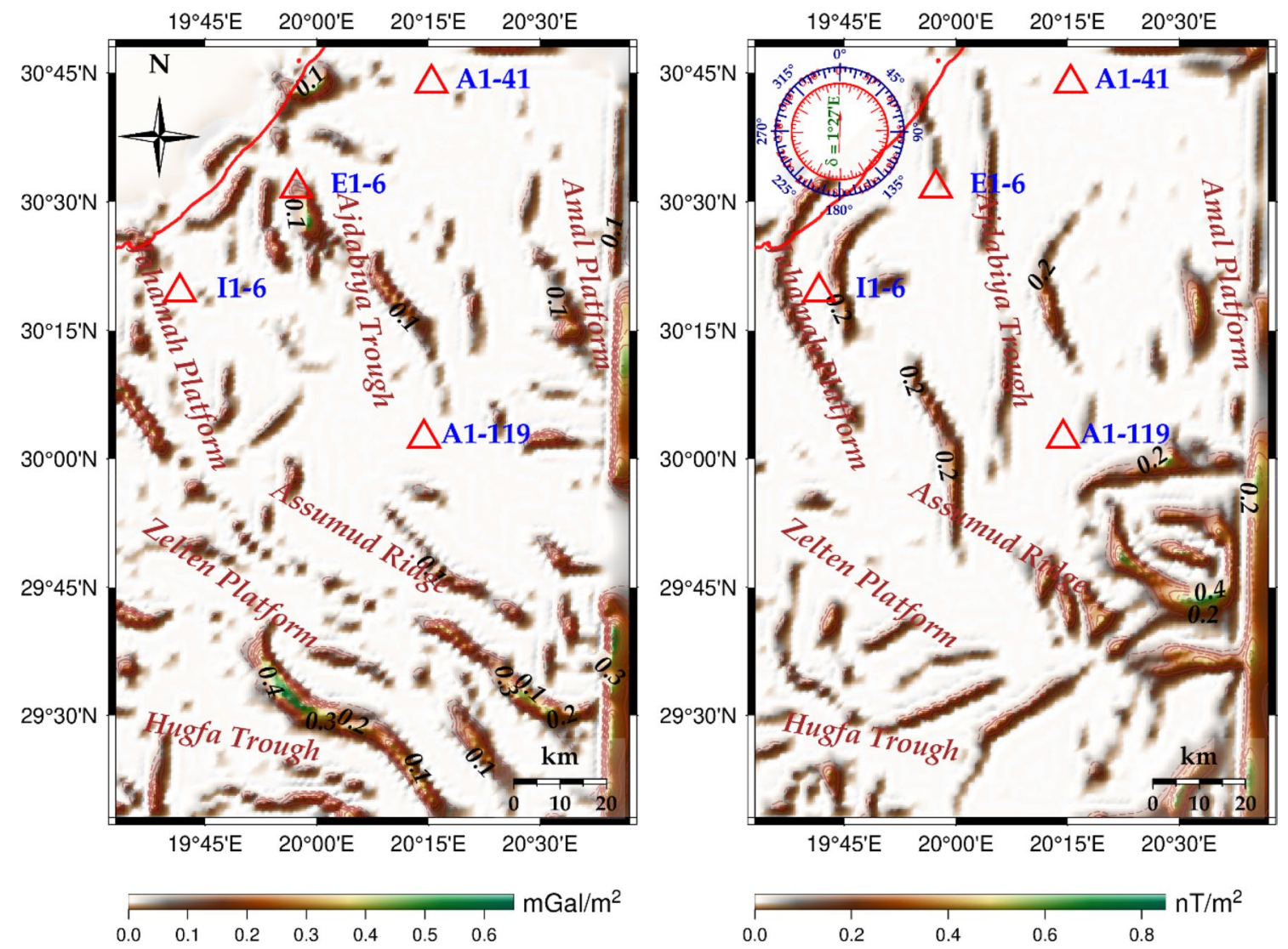

Fig. 8 CET grid analysis maps of a residual Bouguer anomaly, b RTP magnetic anomaly
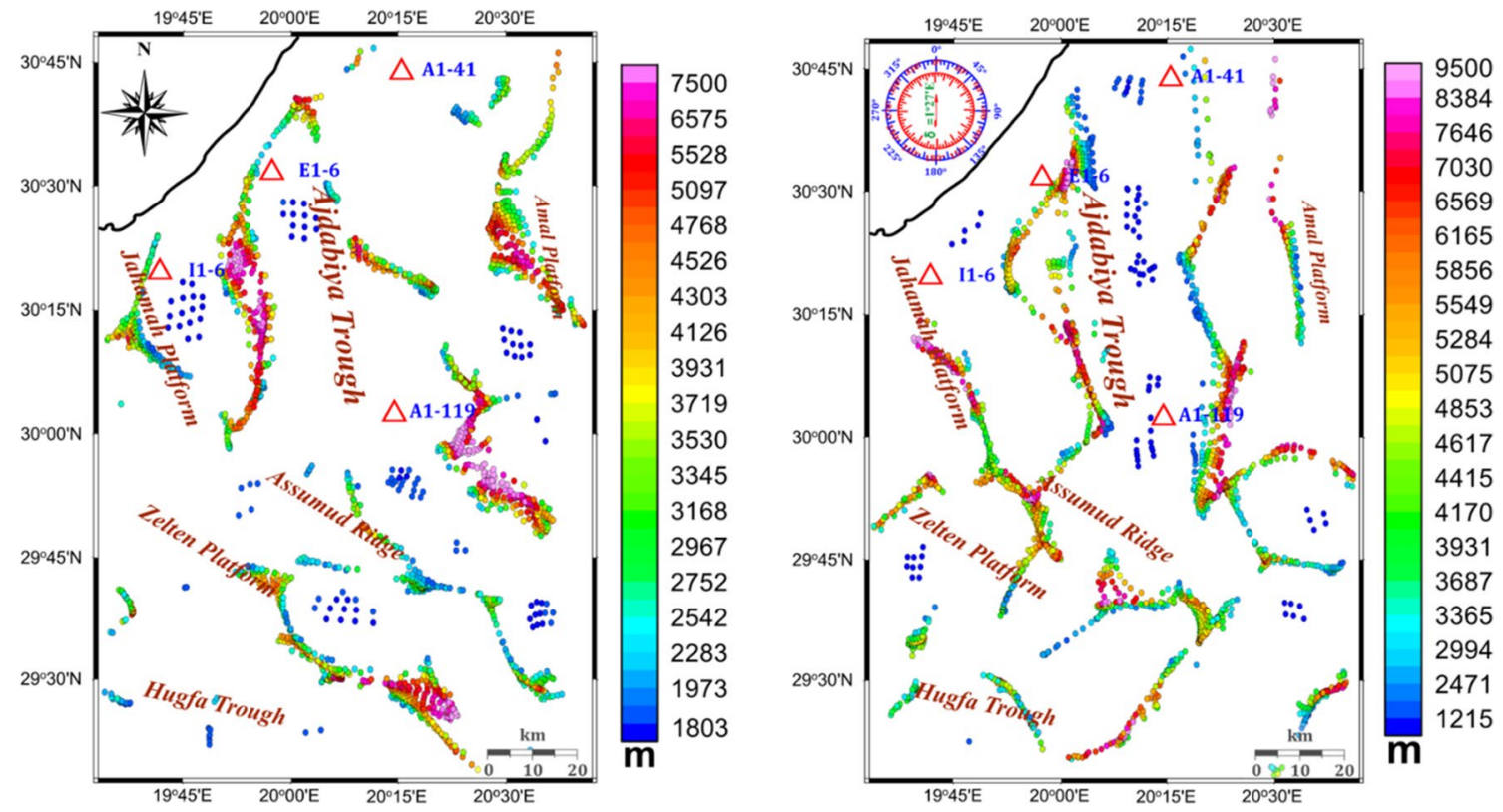

Fig. 9 Euler deconvolution solution maps of a residual Bouguer anomaly, b RTP magnetic anomaly 


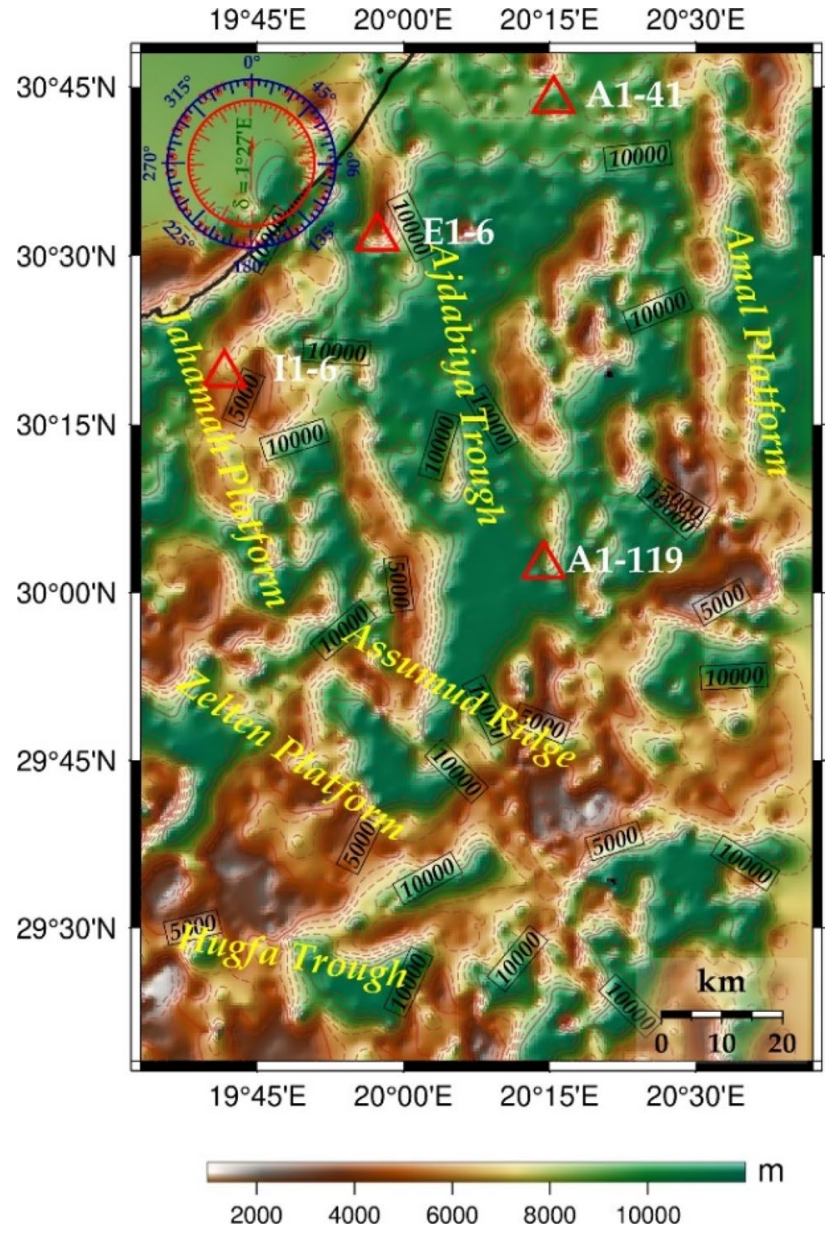

Fig. 10 Source Parameter Imaging (SPI) of RTP magnetic anomaly map showing magnetic source depth distribution across the study area

Shell company has drilled some wells, but details of these wells are not yet public knowledge [36]. Previous studies usually include the trough as part of a wider area of study. Recent studies in close proximity to the study area focus on reservoir formation or hydrocarbon potential, e.g. [32, 33, 36, 54]. However, [34] focused on the structure and stratigraphy of the Ajdabiya Trough which is mostly related to this study. Whereas [34] performed modelling of a single profile in the NW-SE direction to infer three faults, the modelling result of this study (along four profile lines in the E-W and SE-NW directions) identified several different faults. In addition to their trends, the depths of faults are estimated by the 3D Euler deconvolution. The faults inferred from this study penetrated the Cenozoic,
Mesozoic and Paleozoic strata, while the result of previous studies shows that faults ended in the Mesozoic strata.

In the light of newer techniques to analyse data, the results of this study are corroborated by different analytical techniques. For example, the RTP magnetic anomalies are corroborated by the CET counterpart; faults identified by Euler deconvolution show largely similar distribution with the CET anomaly map; fault lines from 2D forward modelling (Fig. 12) align very closely with the Euler deconvolution solution maps (Fig. 9). Unlike studies hitherto, e.g. [34], this study explicitly determined the basement depth beneath the Ajdabiya Trough from both the SPI technique and 2D forward modelling (which are very comparable). This study also determined an intrusion and estimated its geometry, while the previous study suggested intrusions based on magnetic anomalies and previous geological studies which are not based on techniques to detect the geometry of the magnetic anomalies.

The recent development of petroleum exploration relies on the re-examination of known hydrocarbon provinces. Improvements in quality and scope of relevant data have led to the identification of specific areas as important targets for further drilling. Preexisting high structural formation affected the spatial distribution of a reservoir located Southeast of the Ajdabiya Trough and faults are believed to control the distribution and thickness of another reservoir in the same location [33]. While the result of this study has provided more insight into the structure and fault distribution around the Ajdabiya Trough, the result of this study may also inform further studies related to exploration of the trough.

\section{Conclusion}

In this study gravity and magnetic data have been used to obtain the structural trends, direction and depths of faults, as well as depth to the basement within the Ajdabiya Trough. Structural trends control the oil and gas accumulations within the study area. A reservoir located southeast of the Ajdabiya Trough is believed to be structurally controlled by faults. The result of applying different enhancement techniques has been represented in different maps. The gravity and magnetic maps indicate that the study area is marked with elongated gravity anomaly highs (trending NW-SE) and magnetic anomaly lows (trending $\mathrm{N}-\mathrm{S}$ ), showing a strong correlation with the structural 


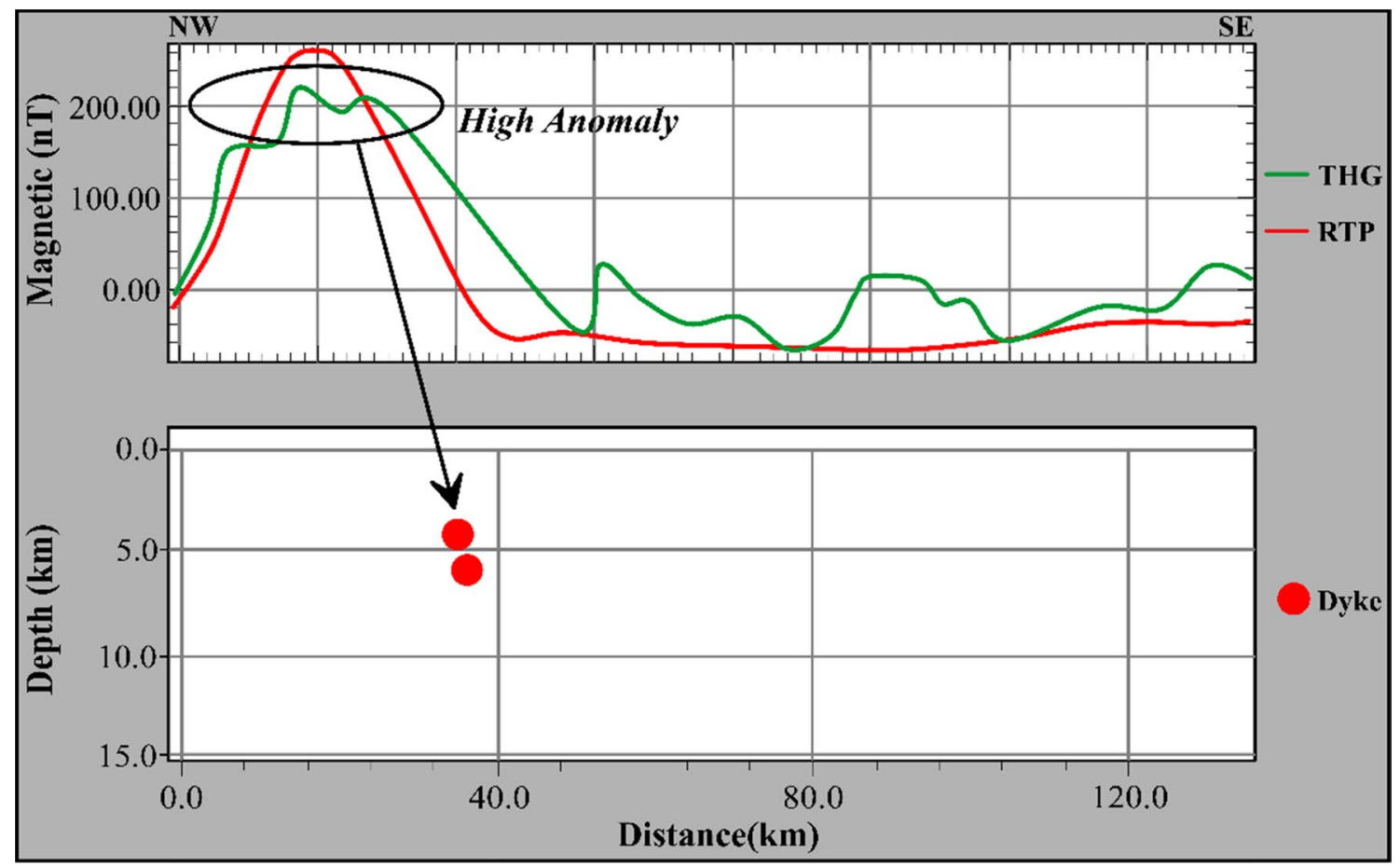

Fig. 11 Werner deconvolution solution across profile line D showing the RTP curve (red line) and THG curve (green line)

highs (associated with platforms) and the structural lows (associated with sedimentary filled troughs). The maps show that Ajdabiya Trough is marked by a long wavelength gravity anomaly lows and highs flanked by steep gravity gradients which delineate faults along the edges. The varying anomalies are the result of different features with varying densities and magnetic susceptibilities. Analysis of residual gravity anomaly shows a NW-SE trending anomalous structure which may be the result of crustal extensions that occurred in the Early Upper Triassic to Early Cretaceous during different phases that formed the Ajdabiya Trough. The analysis of magnetic residual anomaly shows a group of faults with varying trends. These trends represent the faults that occurred after the Pan-African Orogeny. Fault depths range between 1800 and $9500 \mathrm{~m}$.
The result of the Werner deconvolution shows that a high-density causative body is about $4000 \mathrm{~m}$ in depth. The depth to basement beneath the Ajdabiya Trough is about $11,500 \mathrm{~m}$. The basement depth is corroborated by the result of 2D forward modelling which ranges from 9700 to $11,000 \mathrm{~m}$ within the trough. The $2 \mathrm{D}$ forward modelling profiles also show different faults that have penetrated the Cenozoic, Mesozoic and Paleozoic strata beneath the trough. These faults may be the consequence of tectonic events at different times and may play significant roles in reservoir formation within the Ajdabiya Trough. One of the profiles shows an intrusion into the sedimentary section of the area. This is attributable to volcanic activities in the study area. 

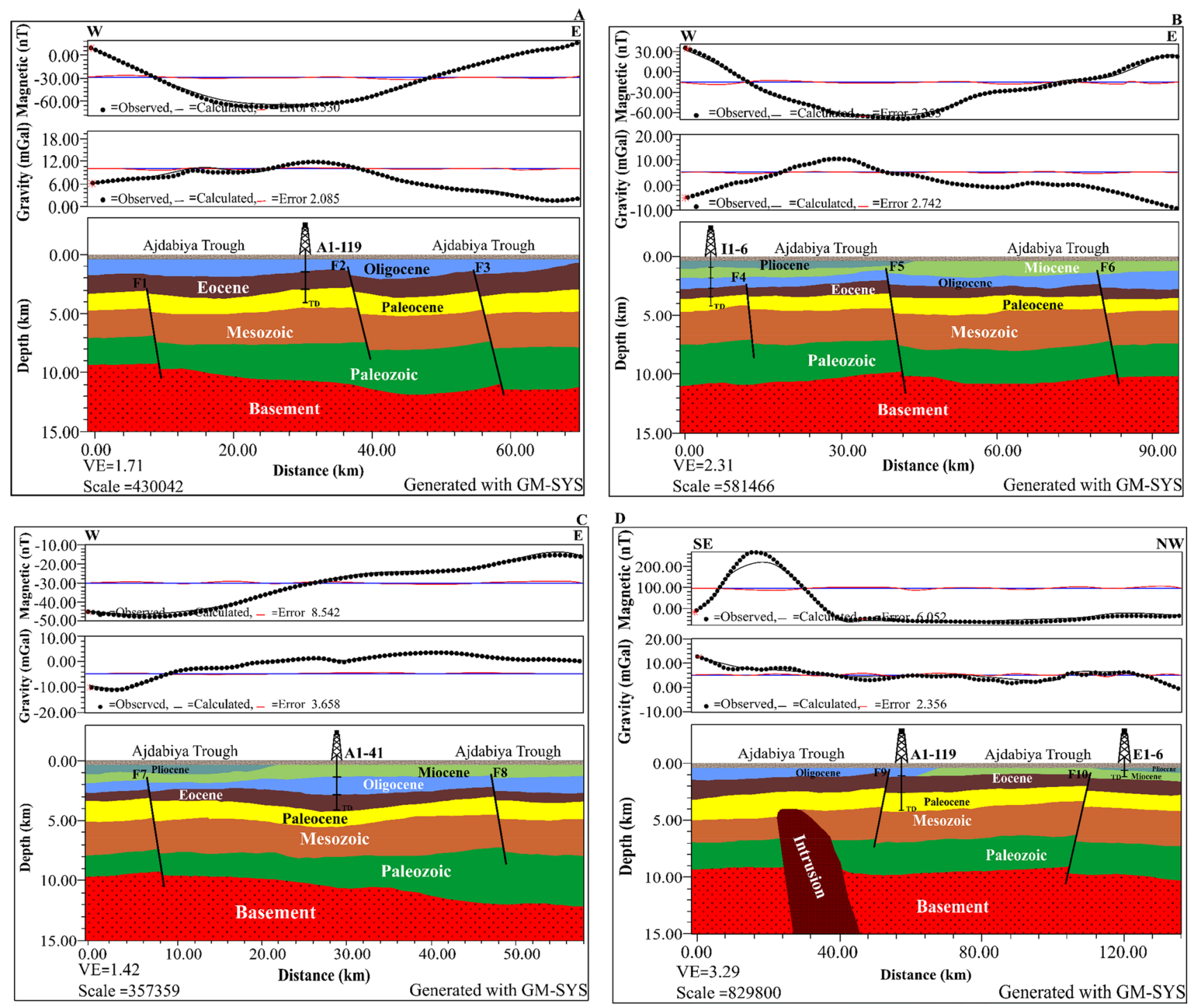

Fig. 12. $2 D$ models from both gravity and magnetic anomalies across four profile lines: a $\mathbf{A}(E-W, 70 \mathrm{~km}), \mathbf{b} \mathbf{B}(E-W, 93 \mathrm{~km}), \mathbf{c} \mathbf{C}(E-W, 58 \mathrm{~km})$ and $\mathbf{d} \mathbf{D}(\mathrm{NW}-\mathrm{SE}, 136 \mathrm{~km})$

Acknowledgements The authors thank the Libyan Petroleum Institute and the African Magnetic Mapping Project for making data available for use in this work. The facilities provided by Universiti Sains Malaysia were also helpful in this study.

Author contributions All authors contributed to the study. Material preparation, data collection and analysis were performed by Abdelhakim Eshanibli. The first draft of the manuscript was written by Abel Uyimwen Osagie, and all authors commented on previous versions of the manuscript. All authors read and approved the final manuscript. Abdelhakim Eshanibli helped in conceptualization, methodology, visualization; Abel Uyimwen Osagie involved in writing-original draft preparation, review and editing; Hussin Ghanush helped in resources and review; Nur Azwin Ismail reviewed the study.

Funding This study is funded by the authors.

\section{Compliance with ethical standards}

Conflict of interest The authors report no conflict of interest.

Availability of data Data used in this study are available at http:// dx.doi.org/10.17632/s3c53pk9g7.1

Open Access This article is licensed under a Creative Commons Attribution 4.0 International License, which permits use, sharing, adaptation, distribution and reproduction in any medium or format, as long as you give appropriate credit to the original author(s) and the source, provide a link to the Creative Commons licence, and indicate if changes were made. The images or other third party material in this article are included in the article's Creative Commons licence, unless indicated otherwise in a credit line to the material. If material is not 
included in the article's Creative Commons licence and your intended use is not permitted by statutory regulation or exceeds the permitted use, you will need to obtain permission directly from the copyright holder. To view a copy of this licence, visit http://creativecommons .org/licenses/by/4.0/.

\section{References}

1. Ahlbrandt TS (2001) The sirte basin province of Libya: Sirt-Zelten total petroleum system. US Geological Survey Bulletin 2202-F

2. Hallett D (2002) Petroleum geology of Libya. Elsevier, Dordrecht, p 297

3. Gong J (2004) Framework for the exploration of Libya: an illustrated summary. AAPG Search Discovery Article 10061

4. Rusk DC (1999) Petroleum potential of the under-explored Basin Centers Libya - a 21st century challenge. AAPG Bull 74(12):1-15

5. Rusk DC (2001) Petroleum potential of the under-explored basin Centers Libya-a 21st-century challenge. AAPG Bull 83:429-452

6. Ghanush H, Imber J, McCaffrey K (2014) Cenozoic subsidence and lithospheric stretching deformation of the Ajdabiya Trough Area, Northeast Sirt Basin, Libya. In: AAPG annual convention and exhibition, USA

7. Abdelnabi AA, Abushalah Y, Liu KH, Gao SS (2019) Integrated geologic, geophysical, and petrophysical data to construct full field geologic model of Cambrian-Ordovician and Upper Cretaceous reservoir formations, Central Western Sirte Basin, Libya. Interpret J 7:21-37. https://doi.org/10.1190/INT-2017-0236.1

8. Wang Y, Eichkitz CG, Schreilechner MG, Heinemann G, Davis JC, Gharsalla M (2016) Seismic attributes for description of reef growth and channel system evolution-case study of Intisar E, Libya. Interpret J 4:1-11. https://doi.org/10.1190/ INT-2015-0017.1

9. Busrewil MT, Oun KM, Haman M (2008) Neoproterozoic-lower Cretaceous Tectono sedimentary evolution of the Sirt Basin. In: Essed AS (ed) Geology of east Libya. Earth Science Society of Libya, Tripoli. pp 251-268

10. Anketell JM (1996) Structural history of the Sirt basin and its relationship to the Sabrata basin and Cyrenaica platform, northern Libya. In: Sola MA (ed) The Geology of the Sirt basin, 1st edn. Elsevier, Dordrecht, pp 57-89

11. El-Batroukh SI, Zentani A (1980) Gravity interpretation of Raguba field, Sirt Basin, Libya. J Geophys 45:1153-1163. https://doi. org/10.1190/1.1441114

12. Skuce AG (1994) A Structural model of a graben boundary fault system, Sirte basin, Libya: compaction structures and transfer zones. Canad J Explor Geophys 30:84-92

13. Baird DW, Aburawi RM, Bailey NJL (1996) Geohistory and petroleum in the central Sirt Basin. In: 1st Symposium, Sedimentary basins of Libya-The geology of Sirt Basin. Elsevier, Netherland, pp 3-56. https://www.tib.eu/de/suchen/id/BLCP\%3ACN019519 964

14. Hallett $D$ (1996) Oil and gas potential of the deep trough areas, in the Sirt Basin, Libya. In: Salem MJ, El-Hawat AS, Sbeta AM (eds) The geology of Sirt Basin, 1st edn. Elsevier, Dordrecht, pp 455-484

15. Burwood R, Redfern J, Cope M (2003) Geochemical evaluation of East Sirte Basin, Libya petroleum systems and oil provenance. Geol Soc Lond Spec Publ 207:203-240. https://doi.org/10.1144/ GSL.SP.2003.207.11

16. Abuhajar MI, Roohi M (2003) Giant Fields in the Sirt Basin, Libya. In: 1st EAGE North African Mediterranean petroleum and geosciences conference and exhibition. European Association of
Geoscientists and Engineers. pp 255-279. https://doi.org/https ://doi.org/10.3997/2214-4609-pdb.8.S025

17. Saadi NM, Aboud E, Saibi H, Watanabe K (2008) Integrating data from remote sensing, geology and gravity for geological investigation in the Tarhunah area, Northwest Libya. Int J Dig Earth 1:347-366. https://doi.org/10.1080/17538940802435844

18. Saadi NM, Aboud E, Watanabe K (2009) Integration of DEM, ETM+, geologic, and magnetic data for geological investigations in the Jifara Plain, Libya. IEEE Trans Geosci Remote Sens 47:3389-3398. https://doi.org/10.1109/TGRS.2009.2020911

19. Saadi NM, Zaher MA, El-Baz F, Watanabe K (2010) Integrated remote sensing data utilization for investigating structural and tectonic history of the Ghadames Basin, Libya. Int J Appl Earth Obs Geoinf 13:778-791. https://doi.org/10.1016/j. jag.2011.05.016

20. Saheel AS, Samsudin AR, Hamzah U (2010) Interpretation of gravity and magnetic anomalies of the Ajdabiya Trough in the Sirte Basin, Libya. Eur J Sci Res 43:316-330

21. Saheel AS, Samsudin AR, Hamzah U (2011) Mapping of faults in the Libyan Sirte basin by magnetic surveys. J Sains Malays 40(8):853-864

22. Gumati YD, Kanes WH (1985) Early Tertiary subsidence and sedimentary facies northern Sirt Basin, Libya. AAPG Bull 69:39-52. https://doi.org/10.1306/AD461B83-16F7-11D7-8645000102 C1865D

23. Gumati YD, Nairn AEM (1991) Tectonic subsidence of the Sirte basin, Libya. J Pet Geol 14:93-102. https://doi. org/10.1111/j.1747-5457.1991.tb00301.x

24. Van Der Meer FC, Sierd C (1993) Intraplate stresses and the subsidence history of the Sirt Basin, Libya. J Tectonophys 226:37-58. https://doi.org/10.1016/00401951(93)90109-W

25. Abadi AM, Van Wees JD, Van Dijk PM, Cloetingh SA (2008) Tectonics and subsidence evolution of the Sirt Basin, Libya. J AAPG Bull 92:993-1027. https://doi.org/10.1306/03310806070

26. Ghanush H (2016) Structure and stratigraphy of the Ajdabiya Trough Area, East Sirt Basin, Libya. Dissertation, Durham University

27. Coward MP, Ries AC (2003) Tectonic development of North African basins. Geol Soc Lond Spec Publ 207:61-83. https://doi. org/10.1144/GSL.SP.2003.207.4

28. El-Makhrouf AA (1988) Tectonic interpretation of JabalEghei area and its regional application to Tibesti orogenic belt, south central Libya. J Afr Earth Sci 7:945-967. https://doi. org/10.1016/0899-5362(88)90009-7

29. Barr FT, Weegar AA (1972) Stratigraphic Nomenclature of the Sirte Basin, Libyan. Petroleum Exploration Society of Libya, Tripoli, Libya

30. Bosworth W, El-Hawat AS, Helgeson DE, Burke K (2008) Cyrenaican "shock absorber" and associated inversion strain shadow in the collision zone of northeast Africa. J Geol 36:695-698. https ://doi.org/10.1130/G24909A.1

31. Casero P, Roure F (1994) Neogene deformations at the SicilianNorth African plate boundary. In: François R (ed) Peri-Tethyan platforms, 1st edn. Tylor, Paris, pp 27-50

32. Gaina C, Torsvik TH, van Hinsbergen DJJ, Medvedev S, Werner SC, Labails C (2013) The African Plate. A history of oceanic crust accretion and subduction since the Jurassic. Tectonophysics 604:4-25. https://doi.org/10.1016/j.tecto.2013.05.037

33. Kassab MA, Abbas AE-S, Teama MA, Khalifa MA (2019) Prospect evaluation and hydrocarbon potential assessment: the lower Eocene Facha non-clastic reservoirs, Hakim Oil Field (NC74A), Sirt Basin, Libya - a case study. J Pet Explor Prod Technol. https ://doi.org/10.1007/s13202-019-00773-8

34. Ghanush H (2019) Structure of the Ajdabiya Trough, NE Sirt Basin, Libya, Derived from Gravity and Magnetic Data. Int J Sci Res 8:1289-1304 
35. Essed AS (1978) A reconnaissance bouguer gravity anomaly map of Libya. Dissertation, Purdue University, United States

36. Hallett D, Daniel C-L (2017) Petroleum geology of Libya. Elsevier, New York

37. Blakely RJ, Simpson RW (1986) Approximating edges of source bodies from magnetic or gravity anomalies. J Geophys 51(7):1494-1498. https://doi.org/10.1190/1.1442197

38. Thurston JB, Brown RJ (1994) Automated source-edge location with a new variable pass-band horizontal-gradient operator. J Geophys 59(4):546-554. https://doi.org/10.1190/1.1443615

39. Miller HG, Singh V (1994) Potential field tilt-a new concept for location of potential field sources. J Appl Geophys 32(2-3):213217. https://doi.org/10.1016/0926-9851(94)90022-1

40. Holden EJ, Wong JC, Kovesi P, Wedge D, Dentith M, Bagas $L$ (2012) Identifying structural complexity in aeromagnetic data: an image analysis approach to greenfield gold exploration. J Ore Geol Rev 46:47-59. https://doi.org/10.1016/j.orege orev.2011.11.002

41. Phillips JD (1998) Processing and interpretation of aeromagnetic data for the Santa Cruz Basin-Patagonia Mountains Area. Southcentral Arizona, US Geological Survey, New York

42. Reid AB, Fitz Gerald D, McInerney P (2004) New discrimination techniques for Euler deconvolution. J Comput Geosci 30:461469. https://doi.org/10.1016/j.cageo.2004.03.006

43. Werner S (1953) Interpretation of magnetic anomalies at sheetlike bodies, vol 7. Geological Survey of Sweden, Stockholm

44. Thurston JB, Smith RS (1997) Automatic conversion of magnetic data to depth, dip, and susceptibility contrast using the SPI (TM) method. Geophysics 62(3):807-813. https://doi. org/10.1190/1.1444190

45. Wessel P, Luis J, Uieda L, Scharroo R, Wobbe F, Smith W, Tian $D$ (2019) The generic mapping tools version 6. Geochem Geophys Geosyst 20(11):5556-5564. https://doi.org/10.1029/2019G C008515
46. Talwani M, Worzel JL, Landisman M (1959) Rapid gravity computations for two-dimensional bodies with application to the Mendocino submarine fracture zone. J Geophys Res 64(1):4959. https://doi.org/10.1029/JZ064i001p00049

47. Rasmussen R, Pedersen LB (1979) End corrections in potential field modeling. J Geophys Prospect 27:749-760. https://doi. org/10.1111/j.1365-2478.1979.tb00994.x

48. Clark D, Emerson D (1991) Notes on rock magnetization characteristics in applied geophysical studies. J Explor Geophys 22:547-555. https://doi.org/10.1071/EG991547

49. Reeves C (2005) Reeves C (2005) Aeromagnetic surveys: principles, practice and interpretation. Geosoft, Toronto

50. Dercourt J, Zonenshain L, Ricou LE, Kazmin V, Le Pichon X, Knipper A, Grandjacquet C, Sbortshikov I, Geyssant J, Lepvrier C (1986) Geological evolution of the Tethys belt from the Atlantic to the Pamirs since the Lias. Tectonophysics 123:241-315. https ://doi.org/10.1016/0040-1951(86)90199-X

51. Jackson J, McKenzie D (1984) Rotational mechanisms of active deformation in Greece and Iran. Geol Soc Lond Spec Publ 17:743-754. https://doi.org/10.1144/GSL.SP.1984.017.01.59

52. Guiraud R, Bosworth W (1998) Senonian basin inversion and rejuvenation of rifting in Africa and Arabia: synthesis and implications to plate-scale tectonics. Tectonophysics 282:39-82. https://doi.org/10.1016/S0040-1951(97)00212-6

53. Guiraud R, Bumby AJ (2005) The geodynamic setting of the Phanerozoic basins of Africa. J Afr Earth Sci 43:1-12. https:// doi.org/10.1016/j.jafrearsci.2005.07.016

54. Burki M, Abu-Khadra A (2019) Sequence stratigraphic approaches for reservoir modeling, Arshad area, Sirt Basin, Libya. J Afr Earth Sci 151:1-8. https://doi.org/10.1016/j.jafrearsci .2018 .11 .01

Publisher's Note Springer Nature remains neutral with regard to jurisdictional claims in published maps and institutional affiliations. 